\title{
原著
}

\section{早期気管支扁平上皮癌剥離細胞中に認められる 角化型異型細胞}

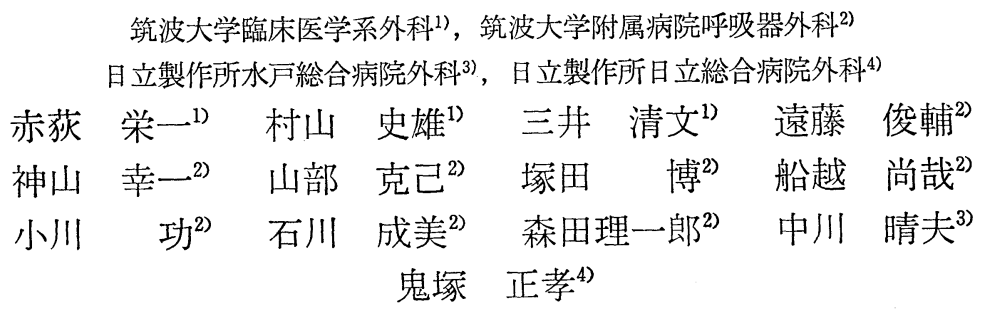

11 例の早期気管支扁平上皮癌を対象にして, 特に腫瘍の最表層の組織像と擦過細胞像を 比較検 討した.

全例角化型扁平上皮癌で, 腫瘍の表層は核濃縮した角化型の癌細胞で覆われていた.

この細胞の擦過細胞像は，核濃縮傾向があり OG 好性の細胞質をむつことが特徽で，その核は 小型で核緣が肥厚し不整形のものが多かった。

腫瘍の最表層を覆う角化型異型細胞は, 喀痰中に最む剝離しやすい細胞であると思われるので, 早期気管支扁平上皮癌の喀痰細胞診によるスクリーニングにおいては，この核形不整のある濃縮核 をむつ角化型細胞に注意することが重要であると思われた。

Key words : Early lung cancer-Cytology of lung cancer-Keratinizing atypical cells

\section{I.はじめに}

喀痰細胞診による気管支扁平上皮癌のスクリーニング

\footnotetext{
Keratinizing atypical cells in exfoliative cytology of bronchogenic early squamous cell carcinoma

Eiichi AKAOGI ${ }^{11}$, M.D., Fumio MURAYAMA ${ }^{11}$, M.D., Kiyohumi MITSUI', M.D., Shunsuke ENDO' ${ }^{2)}$, M.D., Kouichi KAMIYAMA ${ }^{2)}$, M.D., Katsumi YAMABE ${ }^{2)}$, M.D., Hiroshi TSUKADA, M.D., Naoya FUNAKOSHI ${ }^{2)}$, M.D., Isao OGAWA $^{22}$, M.D., Shigemi ISHIKAWA ${ }^{2)}$, M.D., Riichirou MORITA $^{2)}$, M.D., Haruo NAKAGAWA ${ }^{3)}$, M.D., Masataka ONIZUKA $^{4)}$, M.D.

${ }^{11}$ The Department of Surgery, Institute of Clinical Medicine, the University of Tsukuba

${ }^{2)}$ The University of Tsukuba Hospital

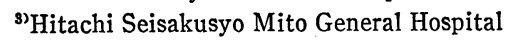

4)Hitachi Seisakusyo Hitachi General Hospital

論文別刷請求先 函305つくば市天王台 1 の 1 の 1 筑波大学 臨床医学系外科 赤荻栄一

昭和 62 年 9 月 3 日受付

昭和 63 年 2 月 26 日受理
}

では角化型異型細胞のチェックが重要であるが，高分化 な角化扁平上皮癌細胞は扁平上皮化生細胞3) との鑑別が しばしば困難であり4)，それが早期癌見落としの原因と なりうる. したがって，早期気管支扁平上皮癌の病巣か ら剝離する角化型異型細胞を検討することはきわめて意 義あることである.

\section{II. 対象亡方法}

喀疾集検で発見され, 当施設および関連病院で切除し た早期気管支扁平上皮癌 11 例を対象とし, 組織標本で, 最表層の数層の細胞の核所見を検討した. すなわち, 腫 瘍の最表層を 400 倍で数視野ずつ観察し, 癌細胞の核所 見によって, 核径 $4 \sim 8 \mu$ の濃縮核をもつ細胞を小型濃 縮核細胞, 核径 $10 \mu$ 前後のものを中型核細胞, $15 \mu$ を 越える核を有するものを大型核細胞，および二核の細胞 に分類して, 症例ごとにその種類別出現頻度を算出し た. 
表 1 早期気管支扁平上皮癌切除例

\begin{tabular}{|c|c|c|c|c|c|c|c|c|}
\hline 症例 & 性 & 年齢 & B.I. & 喀㾳細胞骖 & 原発部 & 最大径 & 肉眼所見. & 浸 潤 \\
\hline 1 & 男 & 72 & 900 & IV & 右 $\mathrm{B}_{7}$ & $3 \mathrm{~mm}$ & 小結節 & 粘膜下 \\
\hline 2 & 男 & 67 & 1,000 & IV & 左 $B_{1+2}$ & 4 & 小結節 & 粘膜下 \\
\hline 3 & 男 & 74 & 1,000 & $\mathrm{~V}$ & 右 $\mathrm{B}_{3}$ & 7 & 分岐部肥厚 & 粘膜下 \\
\hline 4 & 男 & 73 & 1,000 & $\mathrm{~V}$ & 右 $\mathrm{B}_{6}$ & 7 & 不整狭窄 & 粘膜下 \\
\hline 5 & 男 & 78 & 750 & IV & 右 $\mathrm{B}_{3}$ & 8 & 小腫瘤 & 気管支軟骨外 \\
\hline 6 & 男 & 65 & 660 & V & 左 $\mathrm{B}_{3}$ & 9 & 不整狭窄 & 粘膜下 \\
\hline 7 & 男 & 64 & 800 & $\mathrm{~V}$ & 右 $\mathrm{B}_{6}$ & 12 & 小腫瘤 & 粘膜下 \\
\hline 8 & 男 & 69 & 1,500 & IV & 左 $B_{1+2}$ & 13 & 小腫瘤 & 粘膜下 \\
\hline 9 & 男 & 63 & 800 & V & 左上区支 & 15 & 粘膜不整 & 粘膜下 \\
\hline 10 & 男 & 71 & 800 & $\mathrm{~V}$ & 左 $B_{1+2}$ & 22 & 不整狭窄 & 気管支軟骨外 \\
\hline 11 & 男 & 67 & 1,200 & $\mathrm{~V}$ & 左 $B_{3}$ & 32 & 不整狭囬 & 気管支軟骨外 \\
\hline
\end{tabular}

表 2 早期気管支扁平上皮癌腫瘍表層の組織像における角化型細胞

\begin{tabular}{|c|c|c|c|c|c|c|}
\hline \multirow{2}{*}{ 症例 } & \multirow{2}{*}{ 表層角化 } & \multicolumn{2}{|c|}{ 小型濃縮核細胞 } & \multicolumn{2}{|c|}{ 中型核細胞 } & \multirow{2}{*}{$\begin{array}{c}\text { 大型核・ } \\
\text { 二核細胞 }\end{array}$} \\
\hline & & 類门形核 & 不整形核 & 類円形核 & 不整形核 & \\
\hline 1 & 中 & \pm & H & + & + & \pm \\
\hline 2 & 軽 & + & H & \pm & $\#$ & - \\
\hline 3 & 軽 & \pm & + & + & H & \pm \\
\hline 4 & 高 & + & $H$ & + & + & \pm \\
\hline 5 & 中 & \pm & H & \pm & H & \pm \\
\hline 6 & 中 & + & + & + & \# & - \\
\hline 7 & 高 & + & + & + & \# & - \\
\hline 8 & 中 & \pm & $H$ & \pm & H & \pm \\
\hline 9 & 中 & \pm & H & \pm & H & - \\
\hline 10 & 中 & \pm & + & \pm & H & \pm \\
\hline 11 & 高 & \pm & H & \pm & H & - \\
\hline
\end{tabular}

次に, その病巣からの擦過によって得た細胞標本に認 められる角化型異型細胞の細胞所見を組織像と比較検討 した.

\section{III. 結 果}

対象とした 11 例の臨床像と組織学的浸潤度をまとめ ると表 1 のとおりで, 平均年齢は 69.4 歳であり, 通常 の肺癌切除例よりもやや高齢であった．第 9 例は同時性 重複肺癌で, 気管支粘膜下に浸潤が留まる早期癌以外に 気管支壁外へわずかに浸潤した扁平上皮癌を同一肺葉内 に認めた.

各症例の組織像における最表層部の角化の程度と角化 型異型細胞の種類別頻度をまとめたものが表 2 である. 角化型異型細胞の種類別頻度をみると, 角化の程度とは 関係なく，ほとんどの症例で悪性の診断が可能な核形不 整のある中型核細胞を最も多く認めたが，いずれの症例 にも小型濃縮核，特に不整形核をもつ細胞を数多く認め た.また，異型が軽度で扁平上皮化生細胞との鑑別がき
わめて難しい類円形核をもつ細胞も，すべての症例に少 数ながら認められた.

1. 小型濃縮核細胞の細胞所見 (写真 3, 6)

4〜8 $\mu$ の大きさの濃縮核であり，核縁は肥厚し，核小 体は不明瞭であった。 また，くびれや切れ込み，および ゆがみなどの核形不整を認めるものが多いのが特徵であ った. 細胞質はオレンジ $\mathrm{G}(\mathrm{OG})$ に好染し, やや扁平 で不整形ないし類円形のものが多かった. 少数ながら, 小型類円形で核形不整のない濃縮核をもつ細胞があり, これは扁平上皮化生細胞との鑑別は困難で，核濃縮の割 に核は大きさを保ち細胞質にやや厚みがあった.

症例 5 :

組織像は, 粘膜下への浸潤に留まる早期癌で (写真 1), 中等度の角化傾向を示し, 表層は長円形, 類円形および 不整形をした小型濃縮核をもつ扁平な角化型細胞で覆わ れていた (写真 2).

その擦過標本には，核形不整の小型濃縮核をもつ角化 型異型細胞を多く認めた（写真 3-左）．またわずかなが $ら$ ，組織像に一致して，核形不整のない類円形の小型濃 


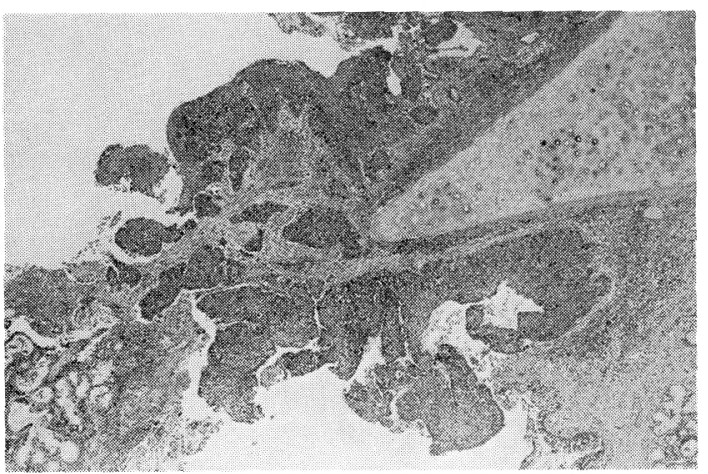

写真 1 症例 5 . 組織像. 浸潤は気管支軟骨には達してい ない $(\mathrm{H}-\mathrm{E}$ 染色, × 40)

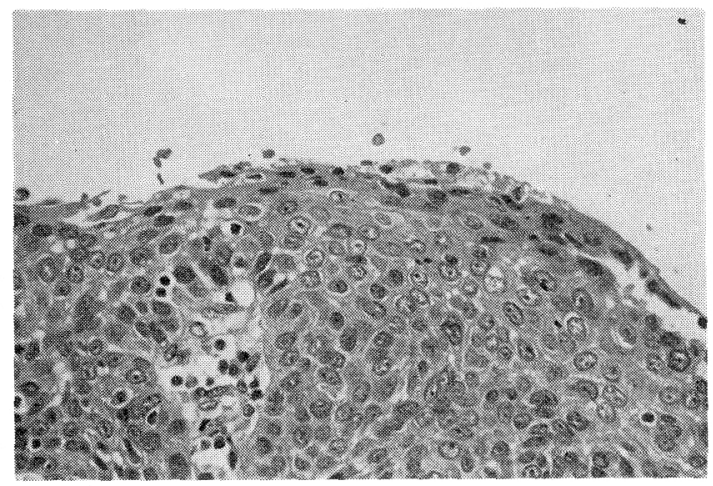

写真 2 症例 5 . 写真 1 の強拡大像. 腫植の表層は小型の 濃縮核をもつ角化型細胞で覆われている(H-E 染 色, $\times 400$ )

縮核をもつ細胞があった。これを癌細胞と認識すること は困難であるが，細胞質にやや厚みがあった（写真 3 右).

\section{症例 10 :}

表層進展型の早期癌（写真 4）で，細胞間橋形成が著 しく，表層の角化は高度であった（写真 5)， その擦過標 本上には, 不整形の小型濃縮核をもつ, 脊平な角化型癌 細胞が多く認められた(写真 6).

\section{2.中型核細胞の細胞所見 (写真 $9,10,13$ )}

核径 $10 \mu$ 前後の角化型細胞で, 悪性と判断しうるも

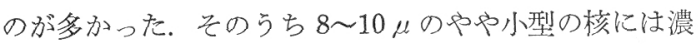
縮傾向学認めるものが多かったが，クロマチンパターン の認識は可能で，榢縁は肥厚し明らかな核形不整戞認め た。檬濃縮傾向のない核は核径 $10 \mu$ 以上やや大型で, クロマチンの增量や榜縁の肥厚を認め, やはり核形不整 があり，乙ばし荄小体を認めた。いずれも細胞質は扁 平で, 形は不整形のものや類円形のものなどさまざまで あった。また，細胞質に層状構造汃变り，明らかに厚文 の增しているものも多かった。

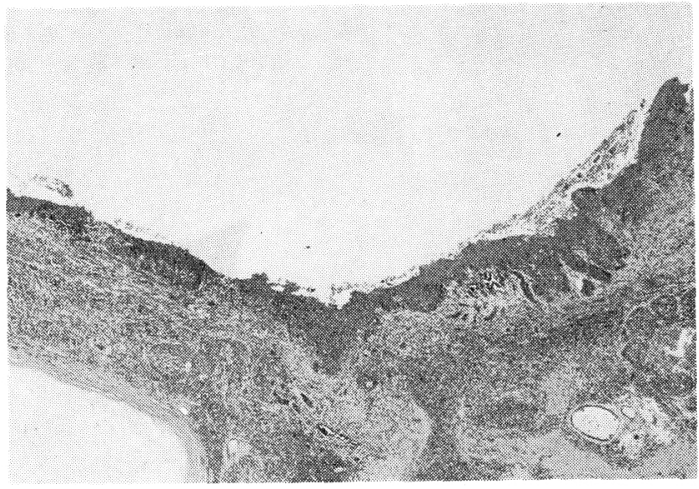

写真 4 症例 10. 組織像。表層進展型の早期癖 (H-E 染色, X40)

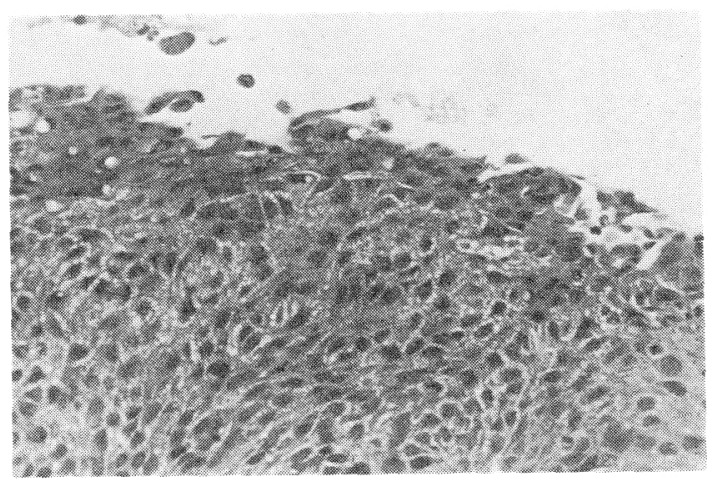

写真 5 症例 10. 写真 4 の強桩大像. 細胞間橋の形成が著 明で核形不整の濃縮核細胞が表層索覆っている (H-E 染色, ×400)

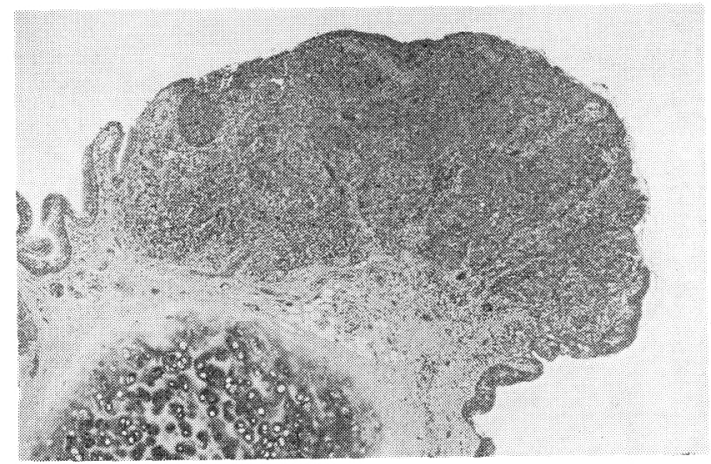

写真 7 症例 2 . 組織像. 浸潤牥粘膜下に留まる最大径 $4 \mathrm{~mm}$ の早期癌 (H-E 染色, × 40)

症例 2 :

最大径 $4 \mathrm{~mm}$ で，気管支粘膜下に浸閵が留まる早期癌 であった (写真 7). 表層の角化はわずかで，不整形小型 濃縮核および不整形中型核をもつ細胞が混在していた (写真 8 ).

その擦過細胞像では，核濃縮傾向があり，核形不整の 


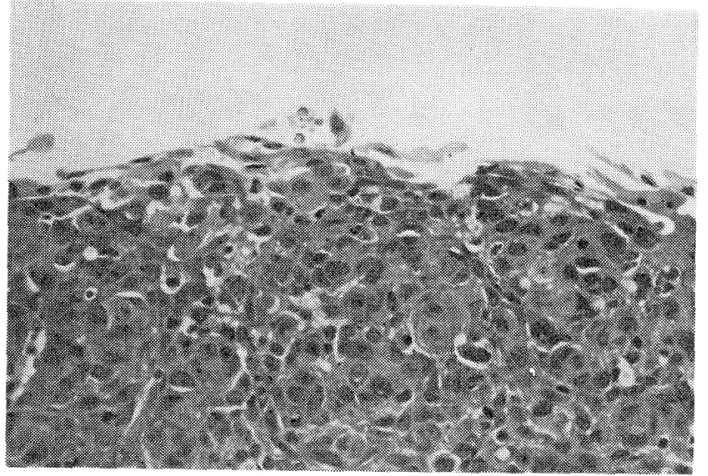

写真 8 症例 2 . 写真 7 の強払大像. 分化の程度は高く ないが表畨には不整形の小型核濃縮細胞が多い ( $\mathrm{H}-\mathrm{E}$ 染色, $\times 400)$

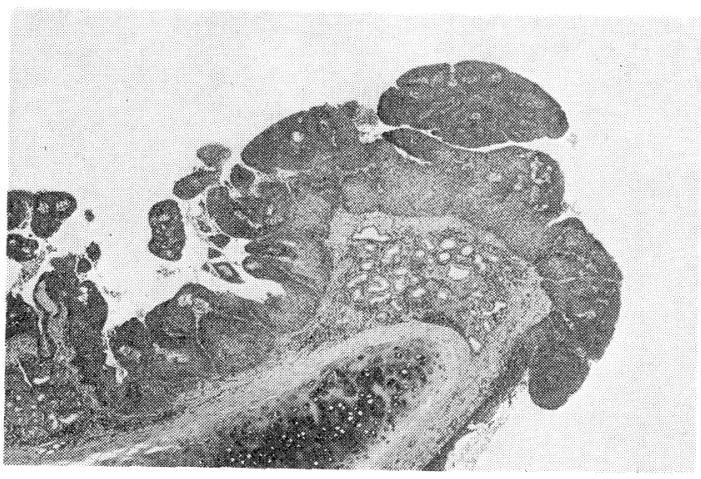

写真 11 症例 3 . 組織像. 最大径 $7 \mathrm{~mm}$ の早期癌で, 気管 支粘膜の基底膜は大部分保たれている( $\mathrm{H}-\mathrm{E}$ 染色。 $\times 40$ )

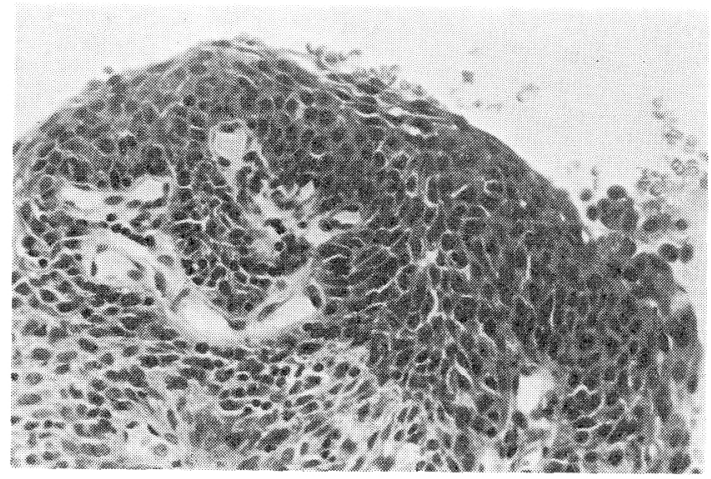

写真 12 症例 3 . 写真 11 の強抾大像. 角化傾向は少ない が，表層は核濃縮した扁平な角化型細胞で覆わ れている (H-E 染色, ×400)

中型核をもつ角化型細胞や，核濃縮傾向は少ないが核形 の不整は明らかで, 癌細胞と容易に判定のできる角化型 細胞が多く認められた（写真 9,10$).$

症例 3 :
$7 \mathrm{~mm}$ の大きさで，気管支粘膜基底膜下にわずかに浸 潤する早期癌であった（写真 11），角化傾向は軽度で， 全体にやや濃縮傾向のある多形性の中型榜を有する細胞 からなり，表層の細胞はわずかに扁平化するのみであっ た (写真 12).

その擦過標本上，核の濃縮傾向があり，核形不整な角 化型細胞や，核形不整は軽度だがクロマチンの増量した 細胞が多数㤠められた（写真 13 )。

3、大型核細胞および二核細胞

核径 $15 \mu$ 以上の核をもつ癌細胞を大型核細胞とした. これらの細胞は6例にわずか化認められたのみであっ t.

\section{IV. 考察}

$\mathrm{Koss}^{2)}$ は，子宮䫫部の角化型上皮内癌の組織像に注目 し，その表層は今回の検討例に認められたと同様の，核 濃縮した成熟角化型細胞で覆われていることを示し, 剝 離細胞中にはその組織像に一致する “悪性細胞の診断基 準を必ずしも満たさない異型細胞”が認められることを 示した。

気管支扇平上皮癌では，上皮内癌の報告例はいまだ少 ないため，上皮内癌での表層角化の様相については不明 だが，早期気管支扁平上皮癌に括いては，佐藤ららによ って呈示された最も多数の早期扇平上皮癌例やWooln$\mathrm{er}^{7)}$ による呈示例に扮いても，その組織像みると，症 例によって出現頻度に違いはあるが，す心゙て表層の大部 分は核濃縮傾向のある成熟した角化型癌細胞で覆われて 以る。

今回検討の対象とした早期気管支扁平上皮癌もす心゙て 角化型で, 程度の差は文るが, やはり全例ともその表層 法化型の扁平上皮癌細胞で覆われていた。この最表層 の細胞が喀痰のなかに最よく剝離する細胞であるか ら，この表層の組織像と表層から擦過剥離した細胞を比 較検討することによって, 早期癌の喀痰細胞診によるス クリーニングに肪いてチェックすべき細胞像を明らかに することができる。

この腫瘍の最表層に認められる核濃縮細胞あるいは㦛 性の診断基準を満たさない細胞については, 現在まで喀 痰細胞診標本で報告されているのみであり，その由来と 形態について詳しく検討した報告はない，Tao ら ${ }^{6)}$ はと の由来を病巣そのものではなく，並存する異型性上皮で あらうと推定した。一方, 橋本ら ${ }^{1}$ は, 喀痰中に出現す る早期癌細胞を表層型と旁基底型とにわけ，特に旁基底 型細胞に注目す心゙きだと報告したが，むしろその報告で 
は重視されなかった表層型細胞が今回報告した核形不整 のある核濃縮角化型異型細胞に相当すると思われ，した がって, その細胞は腫瘍組織に由来するということにな る. また斎藤ら ${ }^{4)}$ も，核濃縮していることが早期癌に特 徵的なことではないとしながらも, それら核異型に乏し い細胞は癌組織に由来するとの考えを示している.

今回の検討で, 早期扁平上皮癌例の喀痰中に認められ る異型の乏しい細胞は, 細胞が最も剥離しやすい, 角化 した表層部に由来するものであることが明らかとなり， この表層の角化型異型細胞をチェックすることが, 早期 扁平上皮癌の喀痰細胞診によるスクリーニングにおいて 重要であることが知られた。

その細胞像の特徴は, OG 好性の細胞質と不整形の濃 縮核をもつことである，核濃縮によりクロマチンパター ンが不明瞭になり,さらに核縁は肥厚し, くびれや切れ 込みなどの核形不整を認めることが特徵である.

特に, 核径が $8 \mu$ 以下の小型濃縮核をもつ細胞が多数 認められ，これらは扁平上皮化生細胞 ${ }^{3)}$ との鑑別が問題 だが，やはりこれらも，核縁は肥厚し核形に不整のある ことが特徴で, その核所見に注目することによって扁平 上皮癌を疑うことができるものである.

この小型濃縮核細胞は, 組織像と擦過細胞像をみる と，かなりの頻度で認められるものであるから，喀痰中 にも相当数認められるはずである.この濃縮核細胞は早 期癌に特徵的な細胞とは限らず, 一般に角化傾向が進む ほど出現頻度が高くなるものと思われるが，早期癌では 角化は腫瘍の表層に向かって進み, 最表層は角化型細胞 が多くを占めるので, 喀痰細胞診による早期癌のスクリ ーニング上, これらの濃縮傾向のある角化型細胞に注目 することが重要であると思われる。この小型濃縮核細胞 を単なる扁平上皮化生細胞と判断して, 早期癌を見逃す ことのないよう注意が必要である.

つまり, これらの核濃縮細胞そのものを注意深く観察 することによっても, 悪性を疑うことは十分に可能であ るが，これらの細胞があれば，ほかに明らかな癌細胞と 判断しうる細胞が必ずあると思われ，少なくともこれら の核濃縮細胞は，たとえそれのみで癌と診断はし得なく とも, ほかに明らかな悪性細胞あるいは悪性を十分に疑 わせる細胞をみつけだす努力のきっかけとなるべき細胞 であり，スクリーニング上最も重要な細胞であると思わ れる.

本研究中, 病理学的検討を行うにあたりご協力を頂きました 筑波大学附属病院病理部 (部長 : 小形岳三郎教授) の方々に哚
謝致します.

本論文の要旨は第 28 回日本臨床細胞学会総会（1987 年 5 月, 大阪）で発表した.

\section{Summary}

In 11 resected cases of the early bronchogenic squamous cell carcinoma, especially the histological findings of the superficial layers of their tumors and the cytological findings of their brushing specimens were examined and compared respectively.

All of them were keratinizing squamous cell carcinoma. And the superficial layers of all the tumors were covered with matured keratinizing cancer cells with pyknotic nuclei.

The keratinizing atypical cells obtained by bronchial brushing were also characterized by the pyknotic nuclei and the eosinophilic cytoplasm. Many of the pyknotic nuclei with thickened chromatinic rim were small and irregularshaped.

It is thought that the keratinizing cancer cells covering the tumors are most likely to exfoliate into sputum. Therefore, in the screening of the early bronchogenic squamous cell carcinoma by sputum cytology, it is very important to take notice of the keratinizing atypical cells with irregularshaped pyknotic nuclei.

\section{文献}

1）橋本武志・他：集検における喀痰細胞診の险路, 喀痰細胞 診による早期発見のアプローチ, 肺癌, $21: 27 \sim 35,1981$.

2) Koss, L.G. : Diagnostic cytology and its histopathologic bases, Third ed., pp. 350 357, J.B. Lippincott, Philadelphia, 1978.

3）日本肺癌学会集団検診委員会：喀疢細胞診における扁平上 皮化生細胞の判定基準, 肺癌集団検診の手びき, 肺癌, $27: 225 \sim 237,1987$.

4）斎藤泰紀 - 他 : 気管支原発早期扁平上皮癌の細胞診断学的 検討, 日臨細胞誌, $24: 686 \sim 698,1985$.

5）佐藤博俊, 斎藤泰紀, 橋本邦久：早期肺癌カラーアトラ ス, pp. 31 154, 金原出版, 東京, 1985.

6) Tao, L.C., et al. : Cytologic diagnosis of radiographically occult squamous cell carcinoma of the lung, Cancer, $50: 1580 \sim 1586,1982$.

7) Woolner, L.B. : Pathology of cancers detected cytologically, Atlas of Early Lung Cancer, pp. 107 213, Igakusyoin, New York, Tokyo, 1983. 


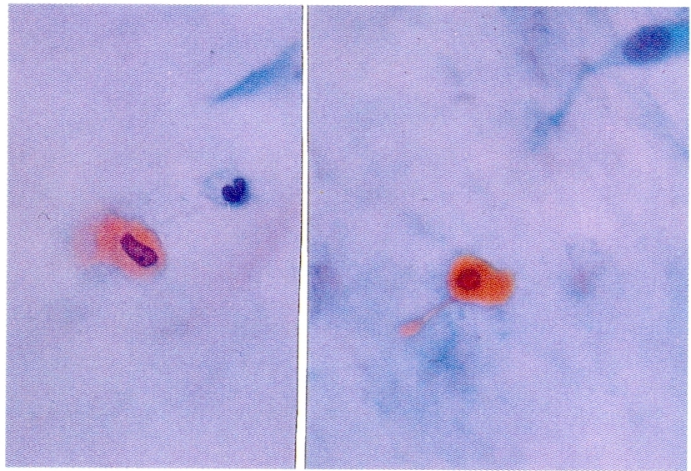

写真 3 症例 5 . 気管支擦過細胞像. 左 : 核にゆがみの岕る 小型濃縮核細胞. 扁平上皮化生細胞との鑑別は難し い. 右 : 小型類円形の濃縮核で, 扁平上皮化生細胞 との鑑別はさらに困難である(Pap. 染色，×1,000)

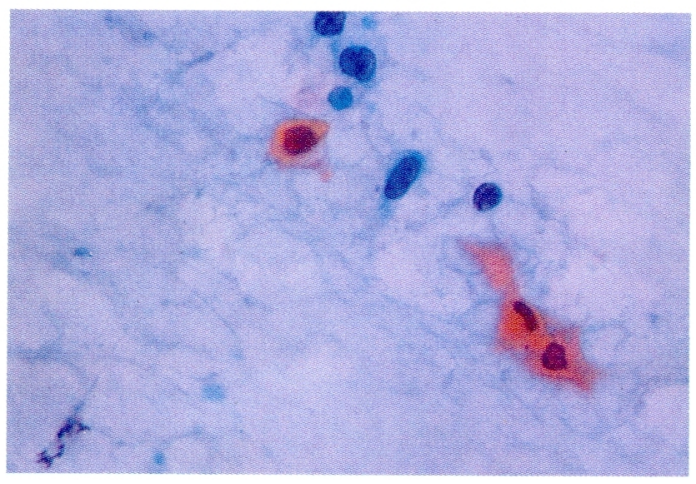

写真 6 症例 10. 気管支擦過細胞像. 核形不整の小型濃縮 核が特徴的な角化型癌細胞 (Pap. 染色, $\times 1,000)$

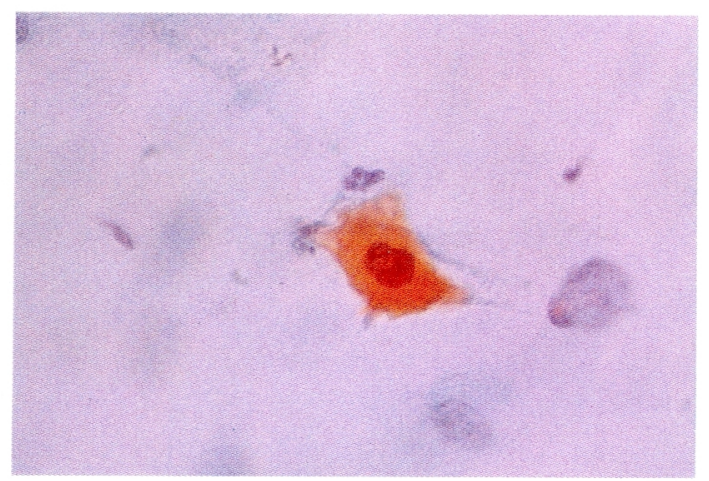

写真 9 症例 2 . 気管支擦過細胞像. 核形不整でクロマチ ン増量した中型核の角化型癌細胞（Pap. 染色, $\times 1,000$ )

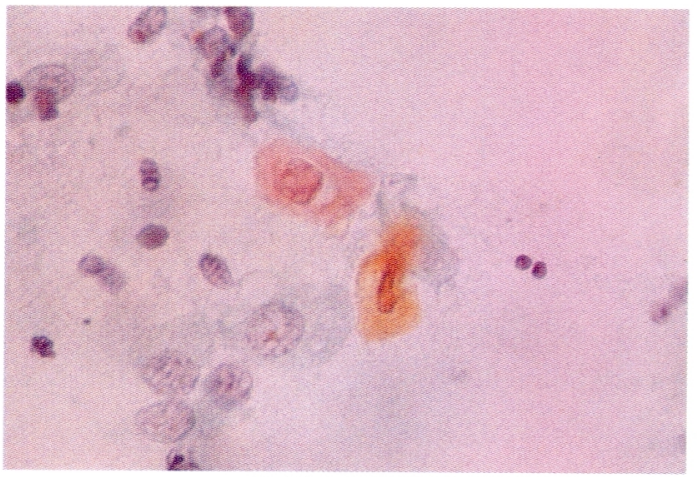

写真 10 症例 2 . 気管支擦過細胞像.上方は核形不整のあ る角化型癌細胞で核小体が目立つ。下方は核濃縮 傾向のある角化型癌細胞（Pap. 染色，×1,000）

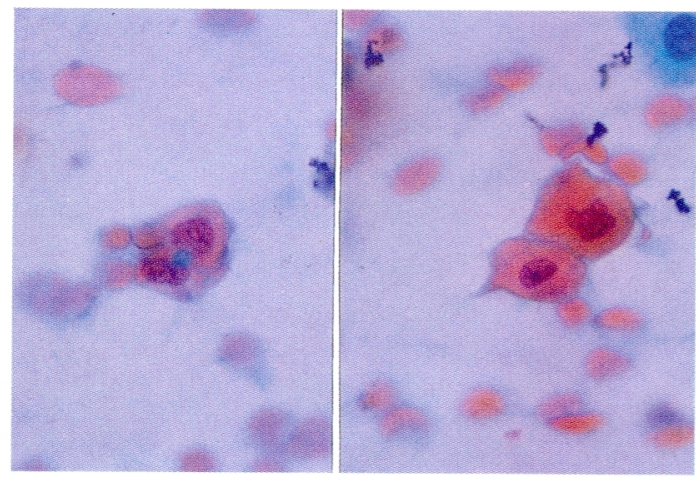

写真 13 症例 3 . 気管支擦過細胞像. クロマチン増量した 角化型癌細胞. 右上はやや核濃縮した二核の癌細 胞 (Pap. 染色, $\times 1,000)$ 